Khanyile MLOTSHWA

College of Humanities, University of KwaZulu-Natal

Pietermaritzburg, South Africa

khanyilemlotshwa@gmail.com

\title{
THE FUTILITY OF CHASING SHADOWS OF PATRIARCHAL LIBERATION: THE AFRICAN NATIONAL CONGRESS WOMEN'S LEAGUE (ANCWL) AND ANTI-COLONIAL FEMINIST POLITICS
}

Recommended Citation: Mlotshwa, Khanyile. "The Futility of Chasing Shadows of Patriarchal Liberation: the African National Congress Women's League (ANCWL) and Anti-colonial Feminist Politics”. Metacritic Journal for Comparative Studies and Theory 4.1 (2018): https://doi.org/10.24193/mjcst.2018.5.04

Abstract: In this paper, I combine critical feminist theories and postcolonial/decolonial feminist theories to examine the persistence of patriarchy in South Africa's postcolonial moment. The postcolonial is taken as both the time that comes after settler rule is over and the recognition that colonialism continues in another form even after settler rule is over (Hall, Post-colonial 244). I ask how is it that at a postcolonial time, when South Africans seem to have made strides on the liberation of women, especially black women, political parties are still reluctant to elect females to lead. Through a close reading of the election of five men and only one woman to lead the ruling African National Congress (ANC) for the next five years as a news event - I argue that the reasons include an ineffectual liberal feminist praxis adopted by the leaders of the African National Congress Women's League (ANCWL) as some kind of 'depoliticised politics' (Jorgensen and Phillips, Wodak and Meyer, Fairclough). This lack of ideological clarity is characterised by reluctance to tackle patriarchy head on by the women leaders.

Keywords: Decolonial feminism, Feminist praxis, Hegemony, Ideology, Patriarchy, Politics, Postcolonial feminism 


\section{Introduction}

Writing on Zimbabwe's postcolonial trajectory, Campbell points to the limits of a patriarchal model of liberation and emancipation (Campbell 268). He notes that the patriarchal model of liberation based on the idea of "the single party and charismatic leader" put emphasis on "national independence" and sacrificed other social struggles linked to it (Campbell 268). As a consequence of this, "the militarist and masculinist leadership turned the victory of the people into a never ending nightmare of direct and structural violence" (Campbell 268). South Africa gained its freedom from punitive apartheid rule in 1994 but for the majority of the people, mostly black women, children and young people, not much has changed as they still live under oppressive conditions in one of the most unequal countries in the world (World Bank, Department of Planning and Monitoring and Evaluation, and Statistics South Africa, 13 - 16). This lack of change has been blamed on the neoliberal policies adopted by the new black government in the early post-apartheid years.

The December 2017 results of the ruling African National Congress (ANC) internal elections stand as an important moment of reckoning for women who are fast realising that the patriarchal model of liberation will not deliver meaningful change for the majority of the people, especially women. At the end of that conference, women in the ANC found themselves at a position similar to 1918 before the formation of the Bantu Women's League (BWL): with no representation in the face of mounting social and political challenges. The 2017 conference was the first time that a woman challenged for the post of president of the party in its 106 years history. An iconic freedom fighter, Nkosazana Dlamini Zuma, formerly the head of the African Union (AU) ran against millionaire businessman, Cyril Ramaphosa. Ramaphosa is a struggle icon as well and is credited with negotiating the country's liberation and the writing of the country's constitution. Dlamini Zuma received 2,261 votes against Ramaphosa's 2,440 votes.

In the other contests where a woman was pitted against a man, David Mabuza beat Lindiwe Sisulu by 2,538 to 2,159 votes for vice president post, and Paul Mashatile beat Maite Nkoana-Mashabane by 2,517 to 2,178 votes for the treasurer general's post. In an all-female contest, Jessie Duarte beat Zingiswa Losi by 2,474 to 2,213 votes for the post of deputy secretary general. In an all-male contest, Gwede Mantashe beat Nathi Mthethwa by 2,418 votes to 2,269 votes for chairman post; and Ace Magashule beat Senzo Mchunu by 2,360 votes to 2,336 votes for the secretary 
general's post. Only one woman, Duarte made it into the top six leadership of the 106 years old party leading to the African National Congress Women's League (ANCWL) chairperson, Bathabile Dlamini, to describe the results as "betrayal of women by the liberation movement". This is despite it being the party's policy that there should be gender parity at all levels.

The ANCWL was shocked by the results although there are several reasons they should have expected the results. First, liberal democracy with its emphasis on merit and capability has continuously disadvantaged minorities in that all the time they find they have to compete with opponents who control and commander far more resources than they do. An election unless controlled through quotas can never deliver such ideals as gender parity. Second, the election was fought between two factions, on gender neutral terms. The faction in a slate headed by the eventual winner, Ramaphosa promised "change" fighting on an anti-corruption stance, which some people saw as a thinly veiled reference to outgoing president, Jacob Zuma. The women's league supported Dlamini Zuma, who was fighting on a Radical Economic Transformation (RET) platform. This was not a women or feminist platform because it was unclear how issues of inequality as it affects women were articulated in the proposed RET agenda. The ANCWL also supported Dlamini Zuma, even though there were two other women campaigning for the presidency: speaker of parliament and former party chairperson, Baleka Mbete, and the minister of human settlements, Lindiwe Sisulu. To many observers, the ANCWL was more embroiled in factional politics at a time when the league should have mounted a serious campaign predicated on feminist politics. The failure by the league to undertake own internal processes and come up with one candidate made some people believe that theirs was not a women issues led campaign.

In this paper, I combine critical feminist theories and postcolonial/decolonial feminist theories to examine the persistence of patriarchy in South Africa's postcolonial moment (Hooks 3, Crenshaw 1241-1299, Carastathis 304-314, McCall 1771-180o, Lugones 742-759, Wynter 257-337, Cusicanqui 95-105). I ask how is it that at a postcolonial time when South Africa seemed to have made strides on women issues, political parties are still reluctant to appoint or elect women to lead. Here the postcolonial is conceptualised as both the time that comes after colonisation and as a time that stands in opposition to colonialism (Hall Post-colonial 56). I use the case of the South African ruling African National Congress (ANC) party elective 
conference held from 16 to 20 December 2017 at the Nasrec Conference Centre in Soweto, Johannesburg, as an entry point to discuss the persistence of patriarchy in the country's post-apartheid politics. This way I seek to make a theoretical contribution to feminist studies in Africa and the world through putting critical feminist theories in dialogue with anticolonial (postcolonial and decolonial) feminist traditions. The paper is organised in such a way that, after this background, I start off by discussing patriarchy from a critical materialist perspective. In the same section, I then discuss postcolonial and decolonial feminist approaches. In the greater part of the paper, I seek to make theoretical discussions around the issues raised during the ANC elective conference, especially the heated debate around patriarchy after the election results were announced. Importantly, I mix theory and an empirical case because I believe empirical cases are likely to give us new theory and theory can prove more useful when used to reflect on empirical cases.

\section{Critical, postcolonial and decolonial feminist theories}

There is no agreement among feminists on the use of the term "patriarchy" with some insisting it is old-fashioned and challenging us to think in "post-patriarchy" terms (Barret and McIntosh 16; Walby 28). However, Enloe warns us, "if you think patriarchy is passe, think again" because it is "as current as Brexit, Donal Trump, and nationalist political parties. It is not old-fashioned, it is as hip as football millionaires and Silicon Valley start-ups". Meade and Hagg define patriarchy as "the system of gender domination rooted in fatherhood" (Meade and Hagg 92). Barret defines it as "the rule of the father in a male-dominated family" (Barret 15). She sees it as ideological construct which considers men as superior to women (Barret 15). Walby sees patriarchy as social structures and practices, systemic, whereby "men dominate, oppress and exploit women" (Walby 28). This system is seen as based on unequal power relations where men control women's production, reproduction and sexuality (Barret and McIntosh 16, Walby 28, Enloe, Meade and Hagg 92).

Barret argues that the term is problematic in that there is confusion over "patriarchy" as the rule of the father and "patriarchy" as the domination of women by men (Barret 16). Walby posits that the problem is not with the term itself but the way it is deployed in differing contexts as some of these tend to be characterised by reductionism, biologism and universalism (Walby 28). In this contribution, I seek to retrieve the concept of the patriarchy for two reasons. The first reason is that, 
allowing patriarchy to hide is part of what gives it power. Second, the ANCWL correctly identifies the challenges in the party as patriarchy. Lerner warns that in conceptualising patriarchy it is important not to think of it as originating or arising at any one specific moment in history (Lerner 233-235). Accepting a historicised approach to patriarchy, Meade and Haag note that "patriarchy in its classical form has not existed in society as father rule exclusively for a very long time" (Meade and Haag 92). They note that it was destroyed by Enlightenment and the social contract of the $17^{\text {th }}$ century with its emphasis on "individual capitalist rationalism" and "instead, father-right was replaced by a broader fraternal-right or domination of society by the "brotherhood of men". So patriarchy has not been one thing throughout history, it has been fluid and taken different shapes and formats. It is patriarchy as the brotherhood of men, the idea that men are better leaders than women, that the ANCWL blames for the dominance of males in their party. When the dominance of the father figure was curtailed in family structures and the father's absolute power over sons was lost, "patriarchy moved to the broader civil society" (Meade and Haag 92). The civil society is the space outside politics. Patriarchy can be traced in a number of spaces in society that include political parties, governments, schools, universities, among others. As recent as 2010, Eggebroteen has traced the persistence of patriarchy in religion where some Christian churches "are still talking about male headship" (Eggebroteen 22). Althusser has identified religion, alongside education, the family, the trade union and the media, as a key site for the reproduction of ideology (Althusser 143). The implications of the reproduction of patriarchy in the church are therefore far reaching in that in these churches, "God is male, all the pastors and deacons, and elders are male, and women are taught to live in submission to men" (Eggebroten 24). Patriarchy is therefore normalised in many social structures and therefore hidden from scrutiny. It is through unmasking it and holding it up to scrutiny that we can imagine a day when males and females can have an equal chance of getting voted into power as idealised by the ANC policies. Enloe points out that exposing how patriarchy works and survives will help "challenge and dismantle" it. Key to the unmasking and holding to scrutiny is the question of "whether patriarchal civil society simply transformed from its basis in the family to a bond among men who exercised control over society and its institutions. Patriarchy could, in Pateman's analysis, be fatherless" (Meade and Haag 92). 
Gordon and Hunter underscore the need for feminists "to theorise power" noting that the absence of the term 'patriarchy' in recent scholarship might signal a lack of emphasis on male power (Gordon and Hunter 71). They further point out that, "more historicised and specific labels are necessary to capture the fact that radical individualization and destruction of community and hierarchy did not bring down male dominance" (Gordon and Hunter 71). Patriarchy is seen as endlessly redesigning itself. Enloe notes that "patriarchy can be updated and modernized. It is stunningly adaptable”.

An important point raised by Enloe is that patriarchal ideas include beliefs and values and can be appealing "not only to most men, but to a lot of women" as well. Beliefs are how we explain the world works and values are what we deem "worthy, good, attractive and well as what we find unworthy, bad, distasteful" (Enloe). Enloe points out that it is important to "think seriously about the appeals and rewards of patriarchy for diverse women". It is important to understand why women at the ANC conference voted for men ahead of women. Enloe characterises such voters as authoritarian voters afflicted by the love for strong men. She posits that, "to be an authoritarian voter is to be someone - of any gender - who yearns for a manly man (or a suitably masculinized woman) to take firm hold of the reins of power and sweep away all the frustrating complexities of constitutional checks and balances" (Enloe). The reasons could be diverse and include the fact that beyond standing on a women's platform or claiming to stand on a women's platform, the women who contested offered nothing different from the males. In another sense, ANC female voters may have felt that they were being made to choose from different brands of patriarchal politics, the difference being that one brand is championed by women.

In the case of the ANCWL, understanding patriarchy as only the domination of women by men might occlude the race and colonial history attached to it, and how these have intersected in the oppression of women in South Africa. The ANC was formed as a movement to fight for the liberation of black people, but in the process emerged questions around women's issues as separate from the general issues of black people. The ANC was formed in 1912 and did not accept membership of women. In 1918, the white racist government of South Africa mooted reintroducing pass laws for women leading to the formation of the Bantu Women's League (BWL) in the same year. The BWL was under the leadership of Charlotte Maxeke and was 
formed as a branch of the ANC. The ANC only accepted women as members of the party at its 1943 congress. The ANCWL was formed in 1948. The specificity of the history of the women's struggles within the broader struggle for liberation has always haunted ANC politics, hence it is not sufficient to look at it from Western centred theory.

This paper combines a materialist approach with postcolonial/decolonial feminist (Spivak subaltern, 24-28; Spivak popular, 475-486; Lugones 742-759) theories in making meaning out of the persistence of patriarchy in South African politics. Postcolonial studies are an interdisciplinary field of inquiry committed to theorising the problematics of colonisation, colonial logics, decolonisation, transnational inequalities, and postcolonial rationalities (Shome and Hegde 250; Shome 245). The whole of Southern Africa can be considered to be postcolonial, although the debates around women emancipation still persist. Except for Malawi, no other country in the Southern African Development Community (SADC) subcontinent has ever been led by a woman. Postcolonial feminism arises out of Spivak's work challenging subalternists in South Asia for failing to account for gender and sexuality in the "postcolonial condition" (Mendoza 108). In her work, she critiques gendered divisions of labour within capitalism, Euro-entricism and interrogates "the epistemic and political borders constructed by neoliberal global capitalism" (Mendoza 108). According to Spivak, the subaltern exists outside the centre and cannot speak for itself (Spivak popular 476). Ozkazanc-Pan posists that the "subaltern", as theorised by Spivak, is "a space to interrupt and question dominant subject positions and, through it, problematizes" technologies of representation such as the media" (Ozkazanc-Pan 575). The decoloniality option is "a particular kind of critical theory" that "names critical thoughts emerging in the colonies and excolonies" (Mignolo 155). The focus of the decoloniality option is to critique coloniality, its hierarchisation of people on a racialized and gendered sliding scale. Giraldo posits that "the decolonial option offers a rich theoretical toolbox for exploring contemporary junctions of gender, race and the question of representation" (Giraldo 157). The decolonial option is, therefore, intersectional, where intersectionality is the study of how race, class, gender, nation, sexuality, ethnicity, age, and other forms of social hierarchy, structure one another as multiple forms of subordination (Collins, 745-773, Hooks 3, McCall 1772). This study of the interaction of multiple systems of oppression and discrimination was first 
highlighted by Kimberle Crenshaw in 1989 and taken up by Patricia Hill Collins in the 1990s. It is impossible to appreciate the historical meaning of the ANC December 2017 election in terms of the political task of building an equal society in South Africa. South Africa is one of the most unequal countries in the world and most of the affected people are women. Men have been at the helm of post-apartheid South Africa since 1994, but have not effectively used their leadership in addressing the inequalities, most of which can be traced to the history of apartheid. In feminist circles, Lugones has combined intersectionality with Quijano's concept of the coloniality of power to develop her own concept of the coloniality of gender (Mendoza, 116). She is, however critical of Quijano's conception of gender as riddled with biological determinism and Eurocentricism. Lugones' argument is that colonised communities did not have the concept of gender before colonisation. However, this has been dismissed by some scholars who argue that gender has always been central to patriarchal pre-colonised societies.

\section{Wrestling the persistence of patriarchy in the postcolonial}

Enloe notes that patriarchy has managed to survive even though "many women have risked their reputations and lives to challenge" it. In a sense, patriarchy as an ideology and a system almost always conditions social structures and institutions in society. Taking after Gramsci, Hall has pointed out how ideologies are strong when they are hidden and are part of the "common sense" ideas of how society operates (Hall, Ideology 56). In most black communities in Africa, it is nearly impossible for people to question why women have to kneel when they give food to men. What started in the domestic family set up and has been extended into the public spaces is by now regarded as part of the traditions and culture of these communities. A cultured woman symbolically defers to a man by kneeling in front of him. In many spaces, beyond the family, patriarchy has managed to hide itself and become common-sensical. As discussed in the introduction above, the idea that there are universal issues or themes, like the unity of the party (in this case the ANC), is a patriarchal idea that has managed to displace other ideas in society and constitute itself as the normative. This is in a scenario where the concerns of women are "domesticated" and seen as "private" issues, while concerns of men are taken as "public" and "political" issues. There is no room to consider that all issues begin as "particularisms" (Bourdieu and Wacquant 41). 
The fact that the agenda and issues as articulated by men took precedence over other issues in the ANC should have been a clear sign of the vitality of patriarchy within the party. It is hard to believe that the ANCWL leaders only realised the masculinist patriarchal politics of the ANC after the December 2017 election results. A plausible argument would be that the ANCWL leaders latched at the opportunity of the results to speak about patriarchy. Following the announcement of the results, they expressed disappointment over the outcome and made reference to "patriarchy" in a long time. The president of the women's league, Bathabile Dlamini spoke about how some of the men who made it into the top six used "the face of a woman" to secure those positions (Davis). Toko Xasa, the league's spokesperson, added that such men "did not pull the candidate up [but] used her as a ladder" noting that "this is how patriarchy is really rearing its ugly head" (Davis). Another woman in the ANC, a senior MP, Cocawe Mafu, also noted that "patriarchy is a big problem in the governing party" (Modjadji). Bathabile Dlamini and Xasa employ the metaphor of women being "used" in politics to illustrate how men see women as a means to an end. Feminist work has pointed to ways in which women's faces are used to market and sell soap, and their bodies used to market and sell cars, but have rarely spoken about how women's faces are used as a way to access positions of power by men.

However, it is possible that the ANCWL leaders were using patriarchy as a scapegoat for the league's strategic failure. Even though they flatly refused to accept or acknowledge the failure of their strategies, there are two issues raised by Bathabile Dlamini that illustrate how they could have been "used" by patriarchy without realising it. First, she notes that if women of the calibre of Dlamini Zuma, Maite Nkoana-Mashabane and Lindiwe Sisulu could not win, "it said a lot about our society" (Khumalo). Second, she notes that the only woman to make it to the top six, Duarte, made it because she was contesting another woman: "If she was facing a man, we would be sitting with an all-male leadership" (Khumalo). The first observation shows that the league has also fallen into the patriarchal trap of creating figureheads out of leaders. It is clear that in Bathabile Dlamini's thinking and in the context of her point, Dlamini Zuma, Maite Nkoana-Mashabane and Lindiwe Sisulu become "masculanized women" who can compete with men shoulder to shoulder (Enloe). This is falling into a patriarchal trap as Bathabile Dlamini imagines the success of women in their struggle in masculinist terms. Her idea of freedom and women liberation is in patriarchal and quantitative (positivist) terms where people 
must win an election. The silence of their campaign on women's issues reveals lack in imagining women's freedom and liberation in qualitative terms. The second example illustrates how patriarchy conveniently sets up women against each other. What is clear is that the two women went up against each other as Trojan horses of opposing slates that were not clear on how the issues they articulated affected them (as women) and others of their gender positioning.

To further illustrate how patriarchy has always lurked in the ANC politics and how it has, to use an Althusserean concept, "hailed" the movement, Bathabile Dlamini evokes the name of a man to argue how the election results are a "historic tragedy". She argues that, "Comrade O.R. Tambo must be turning in his grave, and there is no doubt about that" (Davis). Oliver Reginald Tambo was the president of the ANC who persecuted the liberation war through Umkhonto Wesizwe armed wing of the party from Zambia pre-1994. He is a patriarch of the party alongside people like John Langalibalele, the party's founding president, and Nelson Mandela, the president who took the party into the democratic dispensation post-1994. By evoking the name of Tambo she is reinforcing patriarchy. She should have challenged patriarchy by evoking the name of Charlotte Maxeke, the brave woman who first led the Bantu Women's League when women where threatened with restrictions by the vicious apartheid colonial government in 1918. This was at a time when the ANC, formed in 1912, did not accept, and therefore excluded, women in its membership. The next section, following Bordieu and Wacquant's thesis on the "cunning" of imperialist reason, discusses how patriarchy has a way of making itself seem normal and as a result recruiting people like the leaders of the ANCWL to do its work when they think they are fighting it (Bordieu and Wacquant 41).

\section{The coloniality of universality and women's politics}

Bourdieu and Wacquant note that, "cultural imperialism rests on the power to universalize particularisms linked to a single historical tradition by causing them to be misrecognized as such" (Bourdieu and Wacquant 41). The universalisation of particularism tied to a certain social group could be termed social imperialism. The universal is almost always problematic. The ANC was formed in 1912 with the aim of liberating black people. Ideally, its aims and goals were communicated in such a way that was generalised to mean they focused on the freedom and liberation of all black people. However, in reality, given that it was an all-male organisation, its goals did 
not go far enough to address the concerns of the women. This is why the Bantu Women's League was formed in 1918, focusing specifically on issues that affected black women under the colonial system. When the league became a part of the ANC in 1948, after a conference resolution in 1943, it maintained a modicum of independence in that it joined as an affiliate of the ANC. This is because the women had learned from history that men would not necessarily represent their interests and articulate their issues in their "universal" or "broader" agenda. In a nutshell, maintaining a modicum of independence by joining the ANC as an affiliate structure was a way of saying, to women, the so-called universal or broader agenda of the ANC was historically an agenda particular to men as a social group.

At the 2017 conference, the contrasting reactions to the elections results between men and women betray the entrenchment of patriarchy in the ANC and the tendency to universalize men's agendas and their sensibilities as the norm. The ANC Eastern Cape Provincial Chairperson, Oscar Mabuyane said the outcome of the conference elections as "unity at its best" and will end factionalism. He told the media that "this is unity at its best. We are collapsing the slates." In liberal patriarchal sensibilities, unity is always valued against what is termed divisive sectarian issues. This is even when that unity is mobilised around particularisms tied to a certain social group, in this case men. Mabuyane is therefore speaking commonsensically that unity has succeeded and as a result elides fact that it is women's issues that have lost a place in the party's agenda. In the same sense, the Veterans' League leader, Snuki Zikalala expressed joy at the results saying: "Today the ANC won" (Hunter). This essentialising of the party and downplaying the competing interests in it - women's issues and youth issues to be precise - is the social imperialism of universalising particularisms tied to men's sensibilities and their view of how the world works. Enloe has argued well that patriarchy involves beliefs about how the world works and values about what is of value in the world. True to the masculinist vision of the world, the unity of elites as represented by the two slates is seen as more important than women's issues around inequality that negatively affects nearly 75 percent of the country's population. The ANC KwaZulu-Natal Chairperson, Sihle Zikalala congratulated the new leadership at a plenary session and just saw a continuation of the 106 year old party. This is despite the fact that Sihle Zikalala, as a provincial chairperson, had actively campaigned and supported the same slate as the ANCWL. It becomes clear that he was never invested in the idea of a woman 
president for the party and the country, but was using the ANCWL slate to fight factional battles. Men are always taught to take emotions out of what patriarchy calls "rational" processes like politics. The cunning of patriarchy, then means that there is a need for a different politics to fight it. The next section discusses what a decolonial feminism - as a deliberate disrespect of and delinked from patriarchy and capitalism - could look like.

\section{Towards a self-reflexive decolonial feminist politics}

Tuck and Yang argue that decolonisation is not a metaphor and "when metaphor invades decolonization, it kills the very possibility of decolonization" (Tuck and Yang 3). In a sense they argue for the incommensurability of the decolonisation process to representative politics. Here decolonisation is taken to mean the deliberate process of challenging oppression within patriarchy and patriarchal institutions. Women cannot continue in the hope that men will "represent" their interests and ensure that they are liberated from oppressive social institutions. What is central to this paper is the question of women representation in politics and whether liberal democracy and its institutions and processes such as elections are sufficient to deliver that. Alcoff characterises this as the "crisis of representation", which is located in the possibility of reproducing hierarchies of oppression in (men) speaking for and representing "others" (women) (5-32). Decolonisation challenges liberal democracy and its representative politics by exposing the limits of the idea that a certain social group can "stand" in for another social group, stand in its place and therefore represent it. This liberal politics is a "politics which abolishes politics (...) whereby people no longer speak for themselves" (Neocosmos 333).

In her measured reaction to the election results, a senior woman in the ANC and then minister of small businesses, Lindiwe Zulu, envisions a situation where women will have to continue to represent themselves, but with a change of tactics (feminist praxis). It should be noted that her being a minister of small businesses is tied to the patriarchal idea that it is mostly women who make up this category (small businesspeople). Lindiwe Zulu notes that the ANCWL and all the women in the ANC needed to introspect:

We are disappointed with the fact that there is only one woman in the top six and we feel that it's a step back for us women. At the end of the day, we go back to the 
trenches as women to see where it is that we didn't do right in ensuring that we have got more women because we had two women in the previous official structure and now we have one (Goba and Molatlhwa).

Introspection and self-reflexivity is central to a decolonial politics. Unlike the leaders of the ANCWL who refuse to see what their mistakes and blunders could have been, Zulu points to a need for a well thought out politics. Neocosmos insists that politics must be understood as a "collective thought process" (Neocosmos 332). By using the idea of going back to the trenches, Zulu is gesturing at the possibility of the ANCWL withdrawing from the institutional politics of the ANC to create a space where it can imagine and fashion out new strategies and a new politics. This involves unthinking patriarchal ideas of what women liberation may mean and transcending the idea that it means seizing power as presidents of the party, as this has the effect of portraying women as "people always already failing to seize (state) power" (Ross 74).

Thinking of what women liberation as a decolonial project wants involves thinking beyond the quantitative patriarchal goals of collating votes, and thinking in qualitative terms. For example, after a strong showing, and losing by minor margins, the ANCWL could think of ways they can use the huge support they managed to mobilise around their slate to push through policies that would qualitatively change women's lives. This is important in that, as Zulu points out, for many years "women's struggles in the ANC failed to gain traction in the party because they were reduced to issues of representation in party structures (...) if we take the struggles of women and make them an issue for the ANC Top six, rather that societal issues, then we will keep losing" (Goba and Molatlhwa). Here Zulu is pointing to a strategic process of embedding the women's struggle, in its specificity, in the generality of societal institutions. In a sense, she is advocating for a politics that is able to keep track of patriarchy in all social institutions where it might hide, so that it can be unmasked and challenged. Her hope is that this may lead to a situation where next time women in the ANC may be conscious enough to understand the value of voting for a woman within the context of broader social challenges, importantly inequality.

\section{Conclusion}

Patriarchy endures in many societal institutions and keeps inventing itself. While it is mostly always hidden as common-sense or culture or traditions, it takes moments 
such as the ANC December 2017 elective congress for it to raise its head and be seen. Even in such circumstances, there is still a need to point it out, unmask it and name it so that it can be challenged. These are times when women challenge for leadership positions and seek to disrupt patriarchy's cunning universality. In fashioning a decolonial feminist politics, the ANCWL cannot lose the opportunity afforded them by the December 2017 elective conference to unmask and interrogate the nature of patriarchy in the party and confront it head on. Fanon has pointed out that "decolonisation never takes place unnoticed" (Fanon 36). The dismantling of patriarchy in the party cannot be a secret service operation. It has to be unmasked, identified and "decolonised".

\section{References}

Alcoff, Linda. "The Problem of Speaking for Others". Cultural Critique, vol 20, 1991, pp. 5-32.

Althusser, Louis. On the Reproduction of Capitalism: Ideology and Ideological State Apparatuses. Verso, 2014.

Barret, Michele. Women's Oppression Today: Problems in Marxist Feminist Analysis. Verso, 1980.

Barret, Michele and McIntosh, Mary. “The 'Family Wage': Some Problems for Socialists and Feminists”. Capital and Class, vol 11, 1980, pp. 51-72.

Bourdieu, Pierre and Wacquant, Loic. “On the Cunning of Imperialist Reason”. Theory, Culture and Society, vol 16, issue 1, 1999, pp. 41-58.

Campbell, Horace. Reclaiming Zimbabwe: The Exhaustion of the Patriarchal Model of Liberation. David Philip Publishers, 2003.

Carastathis, Anna. “The Concept of Intersectionality in Feminist Theory.” Philosophy Compass, vol 9, issue 5, 2014, pp. 304-314.

Collins, Patricia, Hill. “The Social Construction of Black Feminist Thought”. Signs: Journal of Women in Culture and Society, vol 14, issue 4, Summer 1989, pp. 745-773.

Crenshaw, Kimberle. "Mapping the Margins: Intersectionality, Identity Politics, and Violence against Women of Colour.” Stanford Law Review, vol 43, 1991, pp. 1241-1299. 
Cusicanqui, Silvia, Rivera. "Chixinakax utxiwa: A Reflection on the Practices and Discourses of Decolonization”. South Atlantic Quarterly, vol 111, issue 1, 2012 , pp. 95-105.

Eggebrroten, Anne. “The Persistence of Patriarchy”. Sojourners, vol 39, issue 7, July 2010, pp. 22-24.

Enloe, Cynthia. “The Persistence of Patriarchy”. New Internationalist Magazine, New Internationalist, October 2017,

https://newint.org/columns/essays/2017/10/o1/patriarchy-persistence. Accessed on 4 March 2018.

Fairclough, Norman. Discourse and Social Change. Polity Press, 1995.

Fanon, Frantz. The Wretched of the Earth. Grove Press, 1963.

Giraldo, Isis. "Coloniality at Work: Decolonial Critique and the Postfeminist Regime”. Feminist Theory, Vol 17, issue 2, 2016, pp. 157-173.

Gordon, Linda and Hunter, Allen. "Not All Male Dominance is Patriarchal”. Radical History Review, Vol 71, 1998, pp. 71-83.

Gramsci, Antonio. Selections from Prison Notebooks. International Publishers, 1971.

Hall, Stuart. “The Rediscovery of 'Ideology': Return of the Repressed in Media

Studies" Culture, Society and the Media, edited by Gurevitch, Michael, Bennet, Tony, Curran, James, and Woollacott, Janet. Methuen, 1982, pp. 56-90.

Hall, Stuart. "When Was 'the Post-colonial'? Thinking at the Limit”. The Postcolonial Question: Common Skies, Divided Horizons, edited by Chambers, Ian and Curti, Lidia. Routledge, 1996, pp 242-260.

Hooks, Bell. Feminist Theory: From Margin to Center. South End Press, 1984.

Jorgensen, Marianne and Phillips, Louise. Discourse Analysis as Theory and Method. Sage, 2002.

Lerner, Gerda. The Creation of Patriarchy: the Origins of Women Subordination. Oxford University Press, 1986.

Lugones, Maria. “Toward a Decolonial Feminism.” Hypatia, vol 25, issue 4, 2010, pp. $742-759$.

Maggio, Jay. “Can the Subaltern Be Heard?': Political Theory, Translation, Representation, and Gayatri Chakravorty Spivak”. Alternatives, vol 32, 1992, pp. 419-443.

McCall, Leslie. “The Complexity of Intersectionality”. Journal of Women in Culture and Society, Vol 30, issue 3, 2005, pp. 1771-1800. 
Meade, Teresa and Haag, Pamela. "Persistent Patriarchy: Ghost or Reality". Radical History Review, vol 71, 1998, pp. 91-95.

Mendoza, Breny. "Coloniality of Gender and Power: From Postcoloniality to Decoloniality". The Oxford Handbook of Feminist Theory, edited by Disch, Lisa and Hawkesworth, Mary. Oxford University Press, 2016, pp. 100-121.

Mignolo, Walter. "Introduction: Coloniality of Power and De-Colonial Thinking”. Cultural Studies, vol 21, issue 2-3, 2007, pp 155-167.

Neocosmos, Michael. "Constructing the Domain of Freedom: Thinking Politics at a Distance from the State”. Journal from Contemporary African Studies, vol 34, issue 3 , 2016, pp 332- 347.

Ozkazanc-Pan, Banu. "Postcolonial Feminist Research: Challenges and Complexities”. Equality, Diversity and Inclusion: An International Journal, vol 31, issue 5/6, 2012, pp. 573-591.

Quijano, Annibal. "Coloniality of Power, Eurocentrism, and Social Classification". Nepantla: Views from the South, Vol 1, issue 3, 2000, pp 533-580.

Ross, Kriss. May'68 and Its Afterlives. University of Chicago Press, 2002.

Shome, Raka. "When Postcolonial Studies Meets Media Studies". Critical studies in Communication, Vol 33, issue 3, 2016, pp. 245-263.

Shome, Raka and Hedge, Radha. "Postcolonial Approaches to Communication: Charting the Terrain, Engaging the Intersections”. Communication Theory, Vol 12, issue 3, 2002, pp. 249-270.

Spivak, Gayatri, Chakravorty. "Can the Subaltern Speak?” The Postcolonial Studies Reader, edited by Ashcroft, Bill, Griffiths, Gareth and Tiffin, Helen. Routledge, 1995, pp. 24-28.

Spivak, Gayatri, Chakravorty. "Scattered Speculations on the Subaltern and the Popular”. Postcolonial Studies, vol 8, issue 4, 2005, pp. 475-486.

Tuck, Eve and Yang, Wayne. "Decolonization is not a Metaphor”. Decolonization: Indigeneity, Education and Society, vol 1, issue 1, 2012, pp. 1-40.

Walby, Sylvia. Theorising Patriarchy. Basil Blackwell, 1990.

Wodak, Ruth and Meyer, Michael. Editors. Methods of Critical Discourse Analysis. Sage, 2009.

World Bank, Department of Planning and Monitoring and Evaluation, and Statistics South Africa. Overcoming Poverty and Inequality in South Africa: An 
Assessment of Drivers, Constraints and Opportunities. International Bank for Reconstruction and Development/The World Bank, 2018.

Wynter, Sylvia. "Unsettling the Coloniality of Being/Power/Truth/Freedom: Towards the Human, After man, Its Overrepresentation - An argument”. CR: The New Centinial Review, vol 3, issue 3, 2003, pp. 257-337.

Yuval-Davis, Nira. "Women, Citizenship and Difference". Feminist Review, vol 57, 1997, pp. $4-27$.

\section{Newspaper stories}

Davis, Rebbeca. “\#ANCdecides2017 Newsflash: Women’s League says OR Tambo 'spinning in his grave' at gender imbalance of top six”. Daily Maverick, 19 December 2017, https://www.dailymaverick.co.za/article/2017-12-19ancdecides2017-newsflash-womens-league-says-or-tambo-spinning-in-hisgrave-at-gender-imbalance-of-top-six/\#.WrzUTIhuY2w. Accessed 5 February 2018.

Goba, Neo and Molatlhwa, Olebogeng. “ANC Women’s League Troubled by Maledominated Top Six", Times Live, 19 Dec. 2017, https://www.timeslive.co.za/politics/2017-12-19-anc-womens-leaguetroubled-by-male-dominated-top-six/. Accessed 5 February 2018.

Hunter, Qaanitah. "New ANC top six 'unity at its best'”. Times Live, 18 December 2017, https://www.timeslive.co.za/politics/2017-12-18-new-anc-top-sixunity-at-its-best/. Accessed 5 February 2018.

Kumalo, Jabu. "We feel betrayed - Dlamini". Daily Sun, 20 December 2017, https://www.dailysun.co.za/News/National/we-feel-betrayed-dlamini20171219. Accessed 5 February 2018.

Modjadji, Ngwako. "ANC wants measures to tackle patriarchy within its ranks". Times Live, 20 December 2017, https://www.timeslive.co.za/anc-conference2017/2017-12-20-anc-wants-measures-to-tackle-patriarchy-within-its-ranks/. Accessed on 5 February 2019.

Molatlhwa, Olebogeng. “'Patriarchy has once again reared its ugly head' - Bathabile Dlamini”. Times Live, 19 December 2017, https://www.timeslive.co.za/politics/2017-12-19-patriarchy-has-once-againreared-its-ugly-head-bathabile-dlamini/. Accessed on 5 February 2018. 